\title{
PENGARUH PENDAPATAN ASLI DAERAH, DANA ALOKASI KHUSUS, DAN LUAS WILAYAH TERHADAP BELANJA MODAL PADA PEMERINTAH KABUPATEN/KOTA DI PROVINSI ACEH
}

\author{
Fajar Maulana ${ }^{1}$, Wida Fadhlia ${ }^{* 2}$ \\ ${ }^{1,2}$ Program Studi Akuntansi Fakultas Ekonomi Universitas Syiah Kuala \\ e-mail: Fajarmaulana9169@ gmail.com $^{1}$, widafadhlia@ unsyiah.ac.id $^{* 2}$ \\ * Corresponding Author
}

\begin{abstract}
This study aims to examine the effect of Local Revenue, Special Allocation Funds, and Area Size on Capital Expenditures. The data used in this study are secondary data obtained from the Aceh Financial Management Agency. The unit of analysis in this study is the 2014-2018 Regency/City Budget Realization Report. The sample in this study was Aceh Province consisting of 23 Regencies/Cities. The analysis technique used is multiple linear regression using SPSS 24. This study uses the independent variables Regional Original Revenue, Special Allocation Funds, and Area and the dependent variable Capital Expenditure. The results of this study indicate that in the simultaneous testing (F test), the variable Local Revenue, Special Allocation Funds, and Area Size have a significant effect on capital expenditure. . In the partial test, the variable of Original Regional Revenue, Special Allocation Funds, and area size affect capital expenditure.
\end{abstract}

Keywords: Capital Expenditure, Influence of Regional Original Revenue, Special Allocation Funds, and Area of Regions

\section{Pendahuluan}

Kebijakan pemerintah melalui Tap MPR No. XV/MPR/1998 menjadi dasar hukum dikeluarkannya Undang-Undang No. 22 Tahun 1999 mengenai pemerintah daerah dan Undang-Undang No. 25 Tahun 1999 mengenai perimbangan keuangan antar pemerintah pusat dan daerah. Menurut Kusnandar (2012) dan Sugiyanta (2016) tujuan dari diberlakukannya desentralisasi ini agar pemerintah daerah (pemda) dapat mengambil kebijakan sesuai dengan aspirasi masyarakat, sehingga dapat terwujudnya kesejahteraan di lingkungan masyarakat dan mendekatkan hubungan antara penyedia pelayanan publik dengan masyarakat luas.

Pemerintah daerah mempunyai kewenangan untuk menggunakan sumber-sumber keuangannya agar dapat dikelola secara efektif dan efisien. Oleh sebab itu, pemda harus menentukan terlebih dahulu perencanaan kegiatan pemerintah dalam satu periode tertentu dalam penyusunan anggaran tahunan (Putra, 2017; Ndede et al., 2017). Berdasarkan pasal 4 Peraturan Pemerintah (PP) No. 58/2005, anggaran sektor publik berisi gambaran dari rencana kegiatan dalam bentuk rencana perolehan pendapatan dan belanja dalam satuan moneter. Anggaran Pendapatan dan Belanja Daerah (APBD), merupakan rencana keuangan tahunan pemerintah daerah yang disusun bersama oleh pemerintah daerah dan DPRD kemudian ditetapkan dengan peraturan daerah.

Salah satu komponen yang terdapat di dalam APBD adalah belanja modal. Pengalokasian belanja daerah di Indonesia selama ini lebih banyak ditujukan untuk belanja pegawai. Penggunaan dana belanja daerah dalam APBD sebaiknya lebih diutamakan untuk hal-hal yang produktif (Felix, 2012). Rata-rata alokasi belanja modal di Indonesia masih pada kisaran 20\% dari APBD. Besaran pengalokasian tersebut masih di bawah dari Peraturan Menteri Dalam Negeri (Permendagri) No. 37 Tahun 2012 yang mewajibkan pemda mengalokasikan belanja modal minimal $30 \%$ dari belanja daerah (Sugiyanta, 2016).

Fenomena di Provinsi Aceh menunjukkan bahwa permasalahan belanja modal sampai saat ini belum mendapat perhatian yang serius dari pemerintah 
Aceh. Hal ini ditunjukkan dari jumlah belanja modal yang dianggarakan untuk APBA pada provinsi Aceh masih di bawah batas minimal ketetapan dari pemerintah pusat yaitu sebesar 30\% untuk belanja modal (Ramlan, 2016).

Untuk membiayai belanja daerah, tentu dibutuhkan pendapatan atau penerimaan yang didapatkan oleh daerah. Penerimaan utama daerah bersumber dari Pendapatan Asli Daerah (PAD) dan dana perimbangan yang akan sangat menentukan jumlah belanja modal (Abdullah, 2015; Ndede et al., 2017). Namun, fenomena yang terjadi pada beberapa pemerintah daerah menunjukkan bahwa kontribusi dari PAD di Indonesia masih relatif sangat kecil jumlahnya dalam struktur APBD (Setiawan, 2010). Realisasi PAD Pemerintah Provinsi Aceh terus meningkat setiap tahunnya. Pada provinsi Aceh, menurut Badan Pusat Statistik (BPS) Provinsi Aceh, angka tersebut masih tergolong rendah, diakibatkan kontribusi PAD terhadap APBA masih di bawah angka $25 \%$.

Pemerintah mengalokasikan dana yang bersumber pada APBN untuk mendanai kebutuhan daerah dalam pelaksanaan desentralisasi. Salah satu dana perimbangan yang ditransfer dari pemerintah pusat ke pemerintah daerah adalah Dana Alokasi Khusus (DAK) (Ndede et al., 2016). Namun, dana ini masih belum dimaksimalkan dengan baik oleh daerahdaerah tertentu yang mendapatkan pembiayaan dari dana ini. Salah satu penyebabnya adalah kurangnya koordinasi dengan pejabat sebelumnya yang tidak mengetahui adanya penyaluran DAK oleh pemerintah pusat serta kurangnya pemahaman pemda dalam menerapkan kebijakan pengelolaan DAK (Karyadi, 2017).

Selain itu, Undang-Undang No. 33 Tahun 2004, menyebutkan bahwa salah satu variabel yang mencerminkan kebutuhan atas penyediaan sarana dan prasarana adalah luas wilayah. Daerah dengan wilayah yang lebih luas tentu membutuhkan sarana dan prasarana yang lebih banyak sebagai syarat untuk pelayanan kepada publik jika dibandingkan dengan daerah dengan wilayah yang tidak begitu luas.

\section{Kerangka Teoritis dan Pengembangan Hipotesis \\ Belanja Modal}

Berdasarkan PSAP Nomor 2, Belanja Modal adalah pengeluaran anggaran untuk perolehan aset tetap dan aset lainnya yang memberi manfaat lebih dari satu periode akuntansi. Selanjutnya pada Permendagri Nomor 59 Tahun 2007 pasal 53 ayat 2 ditentukan bahwa nilai aset tetap berwujud yang dianggarkan dalam Belanja Modal sebesar harga beli/bangun aset, ditambah seluruh belanja yang terkait dengan pengadaan/pembangunan aset sampai aset tersebut siap digunakan. Peraturan Pemerintah No. 24 tahun 2004 tentang Standar Akuntansi Pemerintahan, menjelaskan bahwa Belanja Modal merupakan pengeluaran anggaran yang digunakan dalam rangka memperoleh atau menambah aset tetap dan aset lainnya yang memberikan manfaat lebih dari satu periode akuntansi serta melebihi batasan minimal kapitalisasi aset tetap atau aset lainnya yang ditetapkan pemerintah.

\section{Pendapatan Asli Daerah}

Menurut Undang-Undang Nomor 33 Tahun 2004 tentang Perimbangan Keuangan Antara Pusat dan Daerah pasal 1 angka 18 bahwa Pendapatan Asli Daerah selanjutnya disebut PAD adalah pendapatan yang diperoleh daerah yang dipungut berdasarkan peraturan daerah sesuai dengan peraturan perundangundangan. Menurut Mardiasmo (2002:132) PAD adalah penerimaan daerah dari sektor pajak daerah, retribusi daerah, hasil perusahaan milik daerah, hasil pengelolaan kekayaan daerah yang dipisahkan, dan lain-lain PAD yang sah.

\section{Dana Alokasi Khusus}

Berdasarkan UU No. 33 Tahun 2004, Dana Alokasi Khusus, selanjutnya disebut DAK adalah dana yang bersumber dari pendapatan APBN yang dialokasikan kepada daerah tertentu dengan tujuan untuk membantu mendanai kegiatan khusus yang merupakan urusan daerah dan sesuai dengan prioritas nasional. Besaran DAK ditetapkan setiap tahun dalam APBN. Menurut UU No. 23 Tahun 2014 dan UU No.33 Tahun 2004, wilayah yang menerima DAK harus menyediakan dana penyesuaian paling tidak $10 \%$ dari DAK yang ditransfer ke wilayah, dan dana penyesuaian ini harus dianggarkan dalam anggaran daerah (APBD).

\section{Luas Wilayah}

Wilayah adalah ruang yang merupakan kesatuan geografis beserta segenap unsur terkait padanya yang 
batas dan sistemnya ditentukan berdasarkan aspek administratif dan atau aspek fungsional (Ardhini, 2011). Luas Wilayah merupakan ukuran besarnya daerah wewenang suatu pemerintahan yang dapat diukur dengan satuan angka. Luas Wilayah antara satu daerah dengan daerah yang lainnya memiliki luas yang tidak sama, sehingga kebutuhan akan sarana dan prasarana serta potensi yang dimiliki antara satu daerah dengan daerah yang lainnya pun berbeda (Putra, 2017).

\section{Penelitian Terdahulu}

Penelitian mengenai pengaruh Pendapatan Asli Daerah terhadap Belanja Modal telah dilakukan oleh Sari (2018) mengenai Pengaruh PAD, DAU dan DAK pada Alokasi Belanja Modal dengan Pendapatan Per Kapita Sebagai Pemoderasi. Berdasarkan hasil analisis diketahui bahwa PAD dan DAK berpengaruh positif pada alokasi Belanja Modal sedangkan DAU tidak berpengaruh pada alokasi Belanja Modal. Ini mengindikasikan bahwa besarnya PAD menjadi salah satu faktor penentu dalam menentukan alokasi belanja modal.

Penelitian mengenai Pendapatan Asli Daerah terhadap Belanja Modal juga telah dilakukan oleh Kuntari et al., (2019), mengenai pengaruh Pendapatan Asli Daerah (PAD), Dana Alokasi Umum (DAU), Dana Alokasi Khusus (DAK), dan Dana Bagi Hasil (DBH) mempengaruhi alokasi belanja modal. Hasil penelitian menunjukkan bahwa Pendapatan Asli Daerah (PAD), Dana Alokasi Umum (DAU), Dana Alokasi Khusus (DAK), dan Dana Bagi Hasil (DBH) mempengaruhi alokasi belanja modal. Hasil dalam penelitian ini mengindikasikan bahwa PAD pemerintah daerah Jawa Tengah menentukan pengalokasian belanja modal.

Selanjutnya, Penelitian mengenai Dana Alokasi Khusus terhadap Belanja Modal telah dilakukan oleh Ndede et al., (2016) yang menguji pengaruh Pendapatan Asli Daerah (PAD) dan Dana Alokasi Khusus (DAK) terhadap Pengalokasian Anggaran Belanja Modal Di Kota Manado. Hasil penelitian menunjukkan bahwa secara bersama-sama pendapatan asli daerah dan dana alokasi khusus berpengaruh signifikan terhadap belanja modal pada pemerintah Kota Manado. Hal tersebut menunjukkan bahwa, perkembangan belanja modal Kota Manado masih dipengaruhi oleh Dana Alokasi Khusus.

\section{Kerangka Pemikiran}

Undang-Undang Nomor 33 Tahun 2004 menyebutkan bahwa Pendapatan Asli Daerah merupakan pendapatan yang diperoleh daerah yang dipungut berdasarkan peraturan daerah sesuai dengan peraturan perundang-undangan. Besarnya PAD menjadi salah satu faktor penentu dalam menentukan alokasi belanja modal. Semakin besar PAD yang didapatkan maka berakibat pada semakin besar pengalokasian belanja modal dan berlaku sebaliknya.

Berdasarkan UU No. 33 Tahun 2004, Dana Alokasi Khusus, selanjutnya disebut DAK adalah dana yang bersumber dari pendapatan APBN yang dialokasikan kepada daerah tertentu dengan tujuan untuk membantu mendanai kegiatan khusus yang merupakan urusan daerah dan sesuai dengan prioritas nasional. DAK mempunyai hubungan yang sangat erat dengan alokasi belanja modal karena pendanaannya dari APBN yang ditujukan untuk pembangunan infrasruktur berupa aset tetap, sebagai kegiatan peningkatan serta perbaikan sarana dan prasarana dengan masa manfaat yang panjang. Semakin tinggi nilai transfer DAK maka alokasi belanja modal akan semakin meningkat.

Luas Wilayah merupakan ukuran besarnya daerah wewenang suatu pemerintahan yang dapat diukur dengan satuan angka (Putra, 2017). Luas wilayah dalam hal ini apakah besarannya berpengaruh terhadap jumlah realisasi belanja modal pemerintah yang erat kaitannya dengan peningkatan pelayanan publik. Daerah dengan wilayah yang lebih luas, membutuhkan sarana dan prasarana yang lebih banyak untuk pelayanan kepada publik jika dibandingkan dengan daerah dengan wilayah yang tidak begitu luas. Semakin luas wilayah suatu daerah maka berdampak pada belanja modal yang akan semakin besar pula, berlaku juga sebaliknya.

\section{Hipotesis}

Pendapatan Asli Daerah, Dana Alokasi Khusus, dan Luas Wilayah berpengaruh secara bersama-sama terhadap Belanja Modal pada Pemerintah Kabupaten/Kota di Provinsi Aceh.

1. Pendapatan Asli Daerah berpengaruh terhadap Belanja Modal pada Pemerintah Kabupaten/Kota di Provinsi Aceh. 
2. Dana Alokasi Khusus berpengaruh terhadap Belanja Modal pada Pemerintah Kabupaten/Kota di Provinsi Aceh.

3. Luas Wilayah berpengaruh terhadap Belanja Modal pada Pemerintah Kabupaten/Kota di Provinsi Aceh.

\section{Metode Penelitian}

\section{Desain Penelitian}

Tujuan studi yang ingin dilakukan dalam penelitian adalah pengujian hipotesis. Studi yang termasuk dalam pengujian hipotesis biasanya menjelaskan sifat hubungan tertentu, atau menentukan perbedaan antar kelompok atau kebebasan (independensi) dua atau lebih faktor dalam suatu situasi (Sekaran, 2013:96).

Jenis investigasi dalam penelitian ini ialah kausal (causal study). Penelitian ini melihat pengaruh dari Pendapatan Asli Daerah, Dana Alokasi Khusus, dan Luas Wilayah Terhadap Belanja Modal pada Pemerintah Kabupaten/Kota di Provinsi Aceh. Tingkat intervensi dalam penelitian ini adalah minimum. Situasi studi pada penelitian ini adalah tidak diatur. Unit analisis dalam penelitian ini adalah pemerintah daerah kabupaten/kota di Aceh. Penelitian ini menggunakan data Laporan Realiasi Anggaran APBK Provinsi Aceh pada kurun waktu tahun 2014 sampai dengan tahun 2018. Horizon waktu yang digunakan adalah pooling/panel data.

\section{Populasi dan Sampel Penelitian}

Populasi dalam penelitian ini adalah seluruh kabupaten/kota di Provinsi Aceh yang berjumlah 23 kabupaten/kota, pada tahun 2014 sampai dengan tahun 2018. Penelitian ini menggunakan seluruh populasi yang dijadikan sebagai sampel data penelitian, yang disebut dengan metode sensus. Metode tersebut dipilih karena jumlah populasi relatif kecil dan relatif mudah dijangkau (Sugiyono, 2013:122).

\section{Teknik dan Sumber Pengumpulan Data}

Data yang digunakan dalam penelitian ini adalah data sekunder berupa Laporan Realisasi Anggaran di Provinsi Aceh pada kurun waktu tahun 2014 sampai dengan tahun 2018. Data sekunder merupakan data yang diperoleh melalui sumber yang telah ada dan tidak perlu dikumpulkan sendiri oleh peneliti. Data sekunder biasanya bersumber dari publikasi pemerintah, informasi yang dipublikasikan oleh perusahaan, dokumen perpustakaan, bulletin statistic, data online, website, dan internet (Sekaran, 2013:115). Sumber data dari penelitian ini adalah Badan Pengelolaan Keuangan Aceh (BPKA).

\section{Operasionalisasi Variabel \\ Variabel Dependen (Y)}

Variabel dependen penelitian ini ialah belanja modal. Belanja Modal adalah pengeluaran untuk perolehan aset tetap yang memberikan manfaat lebih dari satu periode akuntansi (PSAP Nomor 2). Data pada penelitian ini akan ditransformasikan ke dalam bentuk Logaritma Natural (LN).

\section{Variabel Independen $(\mathbf{X})$ \\ Pendapatan Asli Daerah (PAD)}

Pendapatan Asli Daerah (PAD) adalah penerimaan dari sumber-sumber daerah sendiri, yang dipungut berdasar peraturan daerah dengan peraturan perundang-undangan yang berlaku yang terdiri dari Hasil Pajak Daerah, Retribusi Daerah, Pendapatan dari Laba Perusahaan Daerah dan lain-lain pendapatan yang sah (Undang-Undang No. 33 Tahun 2004). Data pada penelitian ini akan ditransformasikan ke dalam bentuk Logaritma Natural (LN).

\section{Dana Alokasi Khusus (DAK)}

Dana Alokasi Khusus (DAK) merupakan salah satu dana yang berasal dari APBN yang dialokasikan kepada daerah untuk membiayai kebutuhan tertentu dengan tujuan untuk membantu mendanai kegiatan khusus yang merupakan urusan daerah dan sesuai dengan prioritas nasional (Undang-Undang No. 33 Tahun 2004). Data pada penelitian ini akan ditransformasikan ke dalam bentuk Logaritma Natural $(\mathrm{LN})$.

\section{Luas Wilayah}

Luas wilayah merupakan variabel yang mencerminkan kebutuhan atas penyediaan sarana dan prasarana per satuan wilayah. Maksudnya semakin besar luas wilayah suatu daerah pemerintahan maka semakin banyak juga sarana dan prasarana yang harus disediakan pemerintah daerah agar tersedia pelayanan publik yang baik.Data pada penelitian ini akan ditransformasikan ke dalam bentuk Logaritma Natural $(\mathrm{LN})$. 


\section{Metode Analisis dan Rancangan Pengujian Hipotesis}

\section{Metode Analisis}

Untuk menguji pengaruh PAD (X1), DAK (X2), dan Luas Wilayah (X3), terhadap Belanja Modal (Y) di Kabupaten/Kota di Provinsi Aceh digunakan multiple regression analysis model (model analisis regresi berganda). Model ini dipilih karena penelitian ini hanya untuk menguji pengaruh terhadap belanja modal.

\section{Uji Statistik Deskriptif}

Statistik deskriptif digunakan untuk menggambarkan data yang dapat dilihat dari nilai ratarata (mean), standar deviasi, varian, maksimum, minumun, range, kurtosis dan kemencengan distribusi (skewness) (Ghozali, 2013).

\section{Uji Asumsi Klasik}

Uji asumsi klasik digunakan untuk menguji kelayakan model regresi. Uji asumsi klasik dalam penelitian ini digunakan untuk mengetahui hubungan antar variabel penelitian yang ada dalam model regresi. Pengujian yang digunakan adalah uji multikolinearitas, uji autokorelasi, uji heteroskedastisitas dan uji normalitas.

\section{Rancangan Pengujian Hipotesis}

\section{Analisis Regresi Linear Berganda}

Persamaan regresi adalah sebagai berikut:

$$
\mathrm{Y}=\alpha+\beta 1 \mathrm{X} 1+\beta 2 \mathrm{X} 2+\beta 3 \mathrm{X} 3+\mathrm{e}
$$

\section{Keterangan:}

$$
\begin{array}{ll}
\mathrm{Y} & =\text { Belanja Modal } \\
\alpha & =\text { Konstanta } \\
\beta \text { i:i } & =1,2,3=\text { Koefisien Regresi } \\
\mathrm{X} 1 & =\mathrm{PAD} \\
\mathrm{X} 2 & =\text { DAK } \\
\mathrm{X} 3 & =\text { Luas Wilayah } \\
\mathrm{e} & =\text { error }
\end{array}
$$

\section{Uji Signifikansi Bersama-sama (Uji Statistik F)}

Ketentuan penerimaan atau penolakan hipotesis adalah sebagai berikut:

1. Jika nilai signifikansi $\mathrm{f}>0.05$ maka hipotesis ditolak (koefisien regresi tidak signifikan). Ini berarti bahwa secara simultan ketiga variabel independen tersebut tidak mempunyai pengaruh yang signifikan terhadap variabel dependen.
2. Jika nilai signifikansi $f \leq 0.05$ maka hipotesis diterima (koefisien regresi signifikan). Ini berarti secara simultan ketiga variabel independen tersebut mempunyai pengaruh yang signifikan terhadap variabel dependen.

\section{Uji Signifikansi Parsial}

Pengujian ini melihat berdasarkan dari nilai koefisien regresi $(\beta)$. Penerimaan atau penolakan hipotesis dilakukan dengan kriteria sebagai berikut:

1. Jika nilai Hipotesis Alternatif (Ha): $\beta=0$, maka hipotesis ditolak (koefisien regresi tidak signifikan). Ini berarti bahwa secara parsial variabel independen tersebut tidak mempunyai pengaruh yang signifikan terhadap variabel dependen.

2. Jika nilai Hipotesis Alternatif (Ha): $\beta \neq 0$, maka hipotesis diterima (koefisien regresi signifikan). Ini berarti secara parsial variabel independen tersebut mempunyai pengaruh yang signifikan terhadap variabel dependen.

\section{Koefisien Determinasi $\left(\mathbf{R}^{2}\right)$}

Koefisien determinasi $\left(\mathrm{R}^{2}\right)$ mengukur seberapa jauh kemampuan model dalam menerangkan variasi variabel dependen. Dari sini akan diketahui seberapa besar variabel dependen mampu dijelaskan oleh variabel independen, sedangkan sisanya dijelaskan oleh sebab-sebab lain di luar model.

\section{Hasil dan Pembahasan \\ Hasil Penelitian}

Statistik Deskriptif

\begin{tabular}{|l|c|r|r|r|r|}
\hline & N & \multicolumn{1}{|c|}{ Min } & \multicolumn{1}{c|}{ Max } & \multicolumn{1}{c|}{ Mean } & \multicolumn{1}{c|}{$\begin{array}{c}\text { Std. } \\
\text { Deviation }\end{array}$} \\
\hline PAD & 115 & 23.95 & 26.68 & 25.1777 & .66143 \\
\hline DAK & 115 & 24.03 & 26.67 & 25.5931 & .61125 \\
\hline LW & 115 & 4.12 & 8.75 & 7.3929 & 1.21807 \\
\hline BM & 115 & 25.33 & 26.96 & 26.2033 & .38318 \\
\hline $\begin{array}{l}\text { Valid } \\
\text { N }\end{array}$ & 115 & & & & \\
\hline
\end{tabular}

Sumber: Output SPSS (2020)

Tabel di atas memperlihatkan gambaran atas deskriptif sebuah data yang dapat dilihat dari nilai rata-rata, standar deviasi, maksimum, dan minimum untuk masing-masing variabel dengan jumlah sampel penelitian yang digunakan sebanyak 115 data observasi. Tabel tersebut juga memberikan gambaran tentang ukuran penyebaran data, pemusatan data, serta kecenderungan suatu gugus data. 


\section{Uji Asumsi Klasik}

Uji asumsi klasik digunakan dalam penelitian ini karena untuk melihat apakah dalam persamaan regresi yang sudah ditentukan adalah persamaan yang bisa menghasilkan estimasi yang tidak bias.

\section{Uji Normalitas}

\begin{tabular}{|ll|r|}
\hline & & \multicolumn{2}{|c|}{$\begin{array}{c}\text { Unstandardized } \\
\text { Residual }\end{array}$} \\
\hline $\mathrm{N}$ & & 115 \\
Normal Parameters & Mean & .0000000 \\
& Std. & .30903453 \\
Most Extreme & Deviation & \\
Differences & Absolute & .118 \\
& Positive & .071 \\
Test Statistic & Negative & -.118 \\
Asymp. Sig. (2-tailed) & & .118 \\
\hline
\end{tabular}

Sumber: Output SPSS (2020)

Berdasarkan tabel di atas memperlihatkan bahwa nilai dari Asymp. Sig. (2-tailed) berdistribusi tidak normal, karena nilai Asymp. Sig. (2-tailed) menunjukkan angka $0,000<0,05$. Jika data berdistribusi tidak normal, maka terdapat metode lain yang dapat digunakan untuk menguji normalitas, yaitu menggunakan persamaan regresi secara semilog.

\begin{tabular}{|ll|r|}
\hline & & \multicolumn{2}{|c|}{$\begin{array}{c}\text { Unstandardized } \\
\text { Residual }\end{array}$} \\
\hline $\mathrm{N}$ & Mean & 115 \\
Normal & Std. & .0000361 \\
Parametersa,b & Deviation & 71850572830.00 \\
& Absolute & .080 \\
Most Extreme & Positive & .052 \\
Differences & Negative & -.080 \\
& & .080 \\
Test Statistic & $.065 \mathrm{c}$ \\
Asymp. Sig. (2-tailed) &
\end{tabular}

Sumber: Output SPSS (2020)

Setelah di uji kembali menggunakan metode semilog, maka didapatkan hasil bahwa nilai Asymp. Sig. (2-tailed) telah berdistribusi normal karena nilai Asymp. Sig. (2-tailed) 0,065 > 0,05. Dari hasil tersebut disimpulkan bahwa data telah memenuhi dari syarat uji normalitas.

\section{Uji Multikolonieritas}

\begin{tabular}{|l|r|r|}
\hline \multirow{2}{*}{ Model } & \multicolumn{2}{|c|}{ Collinearity Statistics } \\
\cline { 2 - 3 } & Tollerance & \multicolumn{2}{|c|}{ VIF } \\
\hline Constant & & \\
PAD & .852 & 1.173 \\
DAK & .766 & 1.305 \\
Luas Wilayah & .873 & 1.145 \\
\hline
\end{tabular}

Sumber: Output SPSS (2020)

Berdasarkan tabel di atas, nilai tollerance untuk semua variabel independen berada di atas 0.10 serta VIF (Variance Inflation Factor) variabel independen tidak ada yang diatas 10. Dengan demikian data penelitian ini disimpulkan tidak terjadi gejala multikolinearitas.

\section{Uji Heteroskedastisitas}

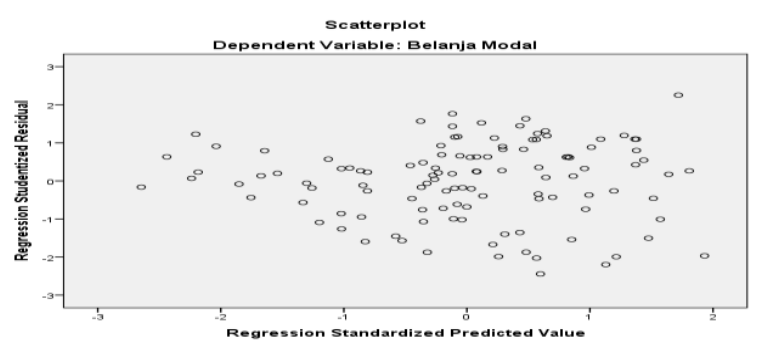

Sumber: Output SPSS (2020)

Berdasarkan Gambar di atas, dapat dilihat titik menyebar di atas dan di bawah sumbu Y, dan tidak memiliki pola yang teratur. Maka dapat diambil kesimpulan variabel bebas di atas tidak terjadi heteroskedastisitas.

\section{Uji Autokorelasi}

\begin{tabular}{|c|c|r|r|r|c|}
\hline $\begin{array}{c}\text { Mod } \\
\text { el }\end{array}$ & $\mathrm{R}$ & $\begin{array}{c}\mathrm{R} \\
\text { Square }\end{array}$ & $\begin{array}{c}\text { Adjusted } \\
\text { R Square }\end{array}$ & $\begin{array}{c}\text { Std. Error of } \\
\text { the Estimate }\end{array}$ & $\begin{array}{c}\text { Durbin } \\
- \\
\text { Watso } \\
\mathrm{n}\end{array}$ \\
\hline 1 & $.607^{\mathrm{a}}$ & .369 & .352 & 72815053200 & 1.907 \\
\hline
\end{tabular}

Sumber: Output SPSS (2020)

Hasil pengujian dari tabel di atas memperlihatkan bahwa pada tingkat signifikansi 0,05 untuk variabel dependen nilai $\mathrm{dw}$ adalah 1,907 dengan nilai $\mathrm{dU}=1,748$ dan nilai 4 -dU $=2,252$ $(1,748<1,907<2,252)$, nilai $d w$ terletak antara nilai $\mathrm{dU}$ dan 4-dU, ini menunjukkan bahwa model regresi tidak terjadi masalah autokorelasi.

\section{Pengujian Hipotesis \\ Hasil Pengujian Hipotesis}

Penelitian ini dilakukan untuk menguji hipotesis dengan menggunakan metode analisis regresi linear berganda (multiple regresion analysis), metode analisis regresi linear berganda bertujuan untuk menganalisis, baik secara parsial maupun secara bersama-sama pengaruh dari Pendapatan Asli Daerah, Dana Alokasi Khusus, dan Luas Wilayah terhadap Belanja Modal. 


\section{Hasil Regresi Linier Berganda}

\begin{tabular}{|l|r|r|c|}
\hline \multirow{3}{*}{ Model } & \multicolumn{2}{|c|}{ Unstandardized Coefficients } & \multicolumn{1}{c|}{ Standardized Coefficients } \\
\cline { 2 - 4 } & \multicolumn{1}{|c|}{ B } & Std. Error & \multicolumn{1}{c|}{ Beta } \\
\hline 1 Constant) & -1971029733000 & 333338913800 & \\
PAD & 30762134350 & 11168967530 & .225 \\
\cline { 2 - 4 } DAK & 50423691360 & 12747148960 & .341 \\
\cline { 2 - 4 } & 22017704680 & 5991928879 & .297 \\
\cline { 2 - 4 }
\end{tabular}

Sumber: Output SPSS (2020)

Berdasarkan dari hasil perhitungan statistik pada Tabel di atas, menghasilkan persamaan regresi linear berganda sebagai berikut:
$\mathrm{BM}=-\mathbf{1 . 9 7 1 . 0 2 9 . 7 3 3 . 0 0 0}+30.762 .134 .350 \mathrm{PAD}+$ 50.423.691.360 DAK+ 22.017.704.680 LS + e

\section{Uji Signifikansi Bersama-sama (Uji Statistik F)}

\begin{tabular}{|l|l|r|r|r|r|c|}
\hline \multicolumn{2}{|l|}{ Model } & Sum of Squares & \multicolumn{1}{c|}{ df } & Mean Square & \multicolumn{1}{c|}{ F } & Sig. \\
\hline 1 & Regression & 343650975800 & 3 & 114550325300 & 21.605 & $.000^{\mathrm{b}}$ \\
& Residual & 58852554900 & 111 & 530203197300 & & \\
& Total & 932176524800 & 114 & & & \\
\hline
\end{tabular}

Sumber: Output SPSS (2020)

Berdasarkan tabel di atas, dapat dilihat bahwa nilai signifikansi diperoleh sebesar 0,000 , dimana nilai signifkansi $\mathrm{F}<0,05$ maka diambil kesimpulan bahwa hipotesis alternative pertama (Ha1) diterima, sehingga secara simultan variabel pendapatan asli daerah, dana alokasi khusus, dan luas wilayah mempengaruhi belanja modal.

\section{Uji Signifikansi Parsial}

\begin{tabular}{|c|c|c|c|}
\hline \multirow[b]{2}{*}{ Model } & \multicolumn{2}{|c|}{ Unstandardized Coefficients } & \multirow{2}{*}{\begin{tabular}{|c|} 
Standardized Coefficient \\
Beta
\end{tabular}} \\
\hline & B & Std. Error & \\
\hline 1 (Constant) & -1971029733000 & 333338913800 & \\
\hline PAD & 30762134350 & 11168967530 & .225 \\
\hline DAK & 50423691360 & 12747148960 & .341 \\
\hline LW & 22017704680 & 5991928879 & .297 \\
\hline
\end{tabular}

Sumber: Output SPSS (2020)

Berdasarkan dari hasil tabel di atas, dapat disimpulkan bahwa:

1) Berdasarkan rancangan pengujian hipotesis yang ditentukan sebelumnya, hipotesis alternatif kedua (Ha2) diterima jika nilai signifikansi hipotesis alternatif $(\mathrm{Ha}): \beta 1 \neq 0$. Variabel pendapatan asli daerah memiliki nilai $\beta 1=30.762 .134 .350$. Hal ini berarti secara parsial pendapatan asli daerah berpengaruh signifikan terhadap Belanja Modal pada Pemerintah Kabupaten/Kota Provinsi Aceh. Dengan demikian, hipotesis alternative (Ha) diterima dan hipotesis nol (H0) ditolak.

2) Hipotesis alternatif ketiga (Ha3) diterima jika nilai signifikansi hipotesis alternatif $(\mathrm{Ha}): \beta 1 \neq 0$.
Variabel dana alokasi khusus memiliki nilai signifikansi $\beta 2=50.423 .691 .360$. Hal ini berarti secara parsial dana alokasi khusus berpengaruh signifikan terhadap Belanja Modal pada Pemerintah Kabupaten/Kota Provinsi Aceh. Dengan demikian, hipotesis alternative (Ha) diterima dan hipotesis nol (H0) ditolak.

3) Hipotesis alternatif keempat (Ha4) diterima jika nilai signifikansi hipotesis alternatif $(\mathrm{Ha}): \beta 1 \neq 0$. Variabel Luas Wilayah memiliki nilai $\beta 3=$ 22.017.704.680. Hal ini berarti secara parsial Luas Wilayah berpengaruh signifikan terhadap Belanja Modal pada Pemerintah Kabupaten/Kota Provinsi 
Aceh. Dengan demikian, hipotesis alternative (Ha) diterima dan hipotesis nol (H0) ditolak.

\section{Koefisien Determinasi $\left(\mathbf{R}^{2}\right)$}

\begin{tabular}{|l|c|r|r|c|}
\hline $\begin{array}{l}\text { Mod } \\
\text { el }\end{array}$ & R & R Square & $\begin{array}{c}\text { Adjusted } \\
\text { R Square }\end{array}$ & $\begin{array}{c}\text { Std. Error of the } \\
\text { Estimate }\end{array}$ \\
\hline 1 & $.607^{\mathrm{a}}$ & .369 & .352 & 72815053200 \\
\hline
\end{tabular}

Sumber: Output SPSS (2020)

Berdasarkan tabel di atas terlihat nilai koefisien determinasi $\left(\mathrm{R}^{2}\right)$ sebesar 0,369 atau yang berarti bahwa sebesar 36,9\% variasi Belanja Modal mampu dijelaskan oleh variasi tiga variabel independen yaitu pendapatan asli daerah, dana alokasi khusus, dan luas wilayah, sedangkan sisanya sebesar $63,1 \%$ dijelaskan oleh variabel lain yang tidak diteliti dalam penelitian ini.

\section{Kesimpulan dan Saran \\ Kesimpulan}

Berdasarkan hasil pembahasan penelitian yang telah dijelaskan sebelumnya, maka dapat disimpulkan bahwa:

1. Pendapatan Asli Daerah, Dana Alokasi Khusus, dan Luas Wilayah berpengaruh secara bersamasama terhadap Belanja Modal pada Pemerintah Kabupaten/Kota di Provinsi Aceh

2. Pendapatan Asli Daerah berpengaruh terhadap Belanja Modal pada Pemerintah Kabupaten/Kota di Provinsi Aceh.

3. Dana Alokasi Khusus berpengaruh terhadap Belanja Modal pada Pemerintah Kabupaten/Kota di Provinsi Aceh.

4. Luas Wilayah berpengaruh terhadap Belanja Modal pada Pemerintah Kabupaten/Kota di Provinsi Aceh.

\section{Saran Praktis dan Akademis Saran Praktis}

1. Bagi peneliti selanjutnya diharapkan memperluas cakupan objek penelitian, tidak sebatas satu daerah tertentu saja. Seperti menggunakan objek penelitian se-sumatera atau menggunakan objek penelitian daerah Indonesia bagian barat ataupun bagian daerah Indonesia lainnya. pada keseluruhan Provinsi yang ada di Indonesia.

2. Menambahkan variabel lain yang tidak dimasukkan dalam penelitian ini.

\section{Saran Akademis}

Bagi Pemerintah Kabupaten/Kota di Provinsi Aceh penelitian ini diharapkan dapat digunakan sebagai bahan evaluasi bagi pemerintah kabupaten/kota di Provinsi Aceh dalam hal pengelolaan keuangan daerah khususnya pada belanja modal, serta sebagai bahan pertimbangan Pemda mengenai pentingnya meningkatkan sumber pendapatan asli daerah, dana alokasi khusus sebagai sumber penerimaan daerah harus dikelola dengan baik agar dapat optimal dalam membiayai belanja modal, serta luas wilayah sebagai bahan perhitungan dalam menentukan jumlah pengalokasian belanja modal.

\section{Daftar Pustaka}

Abdullah, Syukriy dan Abdul Halim. 2004. Pengaruh Dana Alokasi Umum (DAU) dan Pendapatan Asli Daerah Terhadap Belanja Pemerintah Daerah". Simposium Nasional Akuntansi VI, hal 1140-1159.

Abdullah, Syukriy dan Abdul Halim. 2006. Studi atas Belanja Modal pada Anggaran Pemerintah Daerah dalam Hubungannya dengan Belanja Pemeliharaan dan Sumber Pendapatan. Jurnal Akuntansi Pemerintah, 2(2), 17-32.

Abdullah, Syukriy dan Ramadhaniatun Nazry. 2015. Analisis Varian Anggaran Pemerintah Daerah-Penjelasan Empiris dari Perspektif Keagenan. Jurnal Samudera Ekonomi dan Bisnis, 2(2), 272-283.

Abdul Halim dan Theresia Damayanti. 2011. Pengelolaan Keuangan Daerah. Edisi: Kedua. Cetakan: Pertama. Yogyakarta. Penerbit: UPP YKPN

Ardhini dan Handayani, Sri. 2011. Pengaruh rasio Keuangan Daerah Terhadap Belanja Modal Untuk Pelayanan Publik Dalam Perspektif Teori Keagenan (Studi Pada Kabupaten Dan Kota Di Jawa Tengah). Academy of Accounting and Financial Studies Journal. Universitas Diponegoro. Semarang.

Benoit, Kenneth. 2011. Linear Regression Models with Logarithmic Transformations. Methodology Institute, London School of Economics.

Darise. 2008. Akuntansi Keuangan Daerah (Akuntansi Sektor Publik). Indeks. Jakarta.

Direktorat Jenderal Perimbangan Keuangan. 2014. Deskripsi \& Analisis APBD Tahun 2014. Kementerian Keuangan Republik Indonesia. 
Desak Made Mya Yudia Sari, dan Dewa Gede Wirama. 2018. "Pengaruh PAD, DAU dan DAK Pada Alokasi Belanja Modal dengan Pendapatan Per Kapita Sebagai Pemoderasi. E-Jurnal Akuntansi Universitas Udayana. Vol 22(3), 2065-2087

Felix, Olurankinse. 2012. Analysis of the effectiveness of capital expenditure budgeting in the local goverment system of Ondo State, Nigeria. Journal of Accounting and Taxation,4(1), 1-6.

Ghozali, H. Imam. 2013. Aplikasi Analisis Multivariate dengan Program IBM SPSS

22. Semarang: Badan Penerbitan Universitas Diponegoro.

Gujarati, Damodar. 2003. Ekonometri Dasar. Terjemahan: Sumarno Zain, Jakarta: Erlangga.

Handayani, Sri Putri, Syukriy Abdullah, Heru Fahlevi. 2015. Pengaruh Penerimaan Pajak Daerah, Retribusi Daerah dan Dana Bagi Hasil (DBH) Terhadap Belanja Modal di Kabupaten/Kota di Provinsi Aceh. Jurnal Magister Akuntansi Pascasarjana Universitas Syiah Kuala. Vol 4(2), 45- 50.

Halim, Abdul. 2007. Akuntansi Sektor Publik Akuntansi Keuangan Daerah. Jakarta: Salemba Empat.

Junaedy. 2007. Pengaruh Dana Alokasi Umum, Pendapatan Asli Daerah, Dana Bagi Hasil, Sisa Lebih Pembiayaan Anggaran dan Luas Wilayah terhadap Belanja Modal. Jurnal Manajemen dan Akuntansi Future Universitas Yapis Papua. 5878.

Karyadi, Santika Adhi. 2017. "Pengaruh Pendapatan Asli Daerah, Dana Alokasi Umum, dan Dana Alokasi Khusus Terhadap Belanja Modal pada Kabupaten dan Kota Di Provinsi Jawa Tengah Tahun 2011-2014”. Skripsi. Universitas Negeri Yogyakarta

Kasdy, Laila Murhani, Nadirsyah, dan Heru Fahlevi. 2018. "Pengaruh Pendapatan Asli Daerah, Dana Perimbangan, dan Sisa Lebih Perhitungan Anggaran terhadap Belanja Modal dan Implikasinya pada Realisasi Belanja Modal pada Pemerintahan Kabupaten/Kota di Indonesia”. Jurnal Perspektif Ekonomi Darussalam. Vol. 4 (1). 1-18.

Kuntari, Yeni, Anis Chairani, dan Tri Jatmiko Wahyu Prabowo. 2019. Capital Expenditure of Local Governments. Academy of Accounting and Financial Studies Journal Universitas Dipenogoro. Vol. 23(1), 1-13.
Kusnandar dan Dodik Siswantoro. 2012. Pengaruh Dana Alokasi Umum, Pendapatan Asli Daerah, Sisa Lebih Perhitungan Anggaran dan Luas Wilayah Terhadap Belanja Modal. Jurnal dan Prosiding SNA - Simposium Nasional Akuntansi Universitas Indonesia,15(1), 1-20.

Mardiasmo, 2002. Otonomi dan Manajemen Keuangan Daerah. Yogyakarta: Penerbit Andi.

Mason, R. D., \& Lind, D. A. (1996). Teknik Statistika Untuk Bisnis \& Ekonomi (9th ed.). Jakarta: Erlangga.

Mahmudi. 2006. Analisis Laporan Keuangan Pemerintah Daerah Panduan Bagi Eksekutif, DPRD, dan Masyarakat dalam Pengambilan Keputusan Ekonomi, Sosial dan Politik. Yogyakarta:UPP STIM YKPN.

Mahmudi. 2010. Analisis Laporan Keuangan Pemerintah Daerah. Penerbit Erlangga. Jakarta.

Ndede Y., Jullie J. Sondakh, dan Winston Pontoh, 2016. Pengaruh Pendapatan Asli Daerah (PAD) Dan Dana Alokasi Khusus (DAK) Terhadap Pengalokasian Anggaran Belanja Modal Di Kota Manado. Jurnal Berkala Ilmiah Efisiensi. Vol. 16(3), 586-595.

Nufus. H, Jhon A. A. 2017. Pengaruh Pendapatan Sendiri dan Dana Perimbangan terhadap Belanja Modal dengan Dana Otonomi Khusus sebagai Pemoderasi pada Kab/Kota di Provinsi Aceh. Jurnal Ilmiah Mahasiswa Ekonomi Akuntansi (JIMEKA). Vol. 2, No. 3, (2017). 1-9

Nurlis. 2016. The Factors Affecting of the Capital Expenditure Allocation Case: The Local Government of Indonesia. Research Journal of Finance and Accounting, 7(1), pp: 107-113.

Ramlan, Darwanis, Syukriy Abdullah. 2016. Pengaruh Pajak Daerah, Retribusi Daerah, Lain-Lain Pendapatan Asli Daerah Yang Sah, dan Dana Alokasi Khusus Terhadap Belanja Modal (Studi pada Pemerintah Kabupaten/Kota di Provinsi Aceh). Jurnal Magister Akuntansi. Vol. 5(2). 79-88.

Peraturan Menteri Dalam Negri No. 13 Tahun 2006 tentang Pedoman Pengelolaan Keuangan Daerah.

Peraturan Menteri Dalam Negri No. 37 Tahun 2012 tentang Pedoman Penyusunan Anggaran Pendapatan dan Belanja Daerah.

Perarturan Pemerintah Nomor 71 Tahun 2010 tentang Standar Akuntansi Pemerintah. 
Peraturan Menteri dalam Negri Nomor 59 Tahun 2007 tentang Pedoman Pengelolaan Keuangan Daerah.

Peraturan Pemerintah No. 24 tahun 2004 tentang Standar Akuntansi

Pemerintahan.

Peraturan Menteri Keuangan Nomor 101/PMK.02/2011 tentang Klasifikasi Anggaran.

Peraturan Menteri Keuangan Republik Indonesia Nomor 201/PMK.07/2012 tentang Pedoman Umum Dan Alokasi Dana Alokasi Khusus Tahun Anggaran 2013.

Putra, Ferdian. 2017. Pengaruh Desentralisasi Fiskal, Luas Wilayah, dan Sisa Lebih Pembiayaaan Anggaran Terhadap Pengalokasian Belanja Modal (Studi Empiris pada Kabupaten dan Kota di Provinsi Sumatera Barat tahun 2010-2014). E-Journal Univeritas Negeri Padang. 1-22.

Santosa, A.B. Mohamad Ainur Rofiq. 2013. Pengaruh Pendapatan Asli Daerah, Dana Alokasi Umum dan Dana Alokasi Khusus terhadap Belanja Modal pada Kabupaten/Kota (Studi Kasus Di Provinsi Jawa Barat, Jawa Tengah dan Jawa Timur Periode Tahun 2007 - 2010). Jurnal Bisnis dan Ekonomi (JBE).184-198.

Setiawan, Anjar. 2010. Pengaruh Dana Alokasi Umum (DAU) dan Pendapatan Asli Daerah (PAD) terhadap Belanja Daerah (Studi kasus pada Provinsi Jawa Tengah). E-Journal Undip. Vol. 3(1). 1-12.

Sugiyanta. 2016. Analisis Belanja Modal dan FaktorFaktor yang Mempengaruhinya pada Pemerintah Kabupaten/Kota di Indonesia. Jurnal Akuntansi Universitas Jember, 14(1), 19-38.

Sugiyono. 2013. Metode Penelitian Kuantitatif, Kualitatif dan R\&D. Bandung: Penerbit Alfabeta.

Sekaran, Uma., Roger Bougie. 2013. Research Methods For Business. Edisi 4. Buku 2, Jakarta: Wiley.

Undang-Undang No. 9 Tahun 2015 tentang Pemerintahan Daerah.

Undang-Undang Nomor 11 Tahun 2006 tentang Pemerintah Aceh.

Undang-Undang No. 33 Tahun 2004 tentang Perimbangan Keuangan Antara Pemerintah Pusat dan Pemerintah Daerah.

Undang-Undang No. 28 Tahun 2009 tentang Pajak daerah dan Retribusi Daerah. www.bpka.acehprov.go.id

www.acehprov.go.id.

www.aceh.bps.go.id 